\title{
Reconsidering the science of scientific whaling
}

\author{
Peter J. Corkeron* \\ Bioacoustics Research Program, Cornell Laboratory of Ornithology, 159 Sapsucker Woods Road, Ithaca, New York 14850, USA
}

\begin{abstract}
Scientific whaling is one of the most publicly contentious applications of marine ecological research today. An evaluation of the second phase of Japan's Institute of Cetacean Research (ICR) program in the western North Pacific (JARPN II) is soon to be conducted under the auspices of the Scientific Committee (SC) of the International Whaling Commission (IWC). Previous IWC SC reviews identified serious problems with the programs, yet reached inconsequential conclusions, and the JARPN II review is the first under a new format. The basic design of this study - forestomach sampling coupled with acoustic and trawl surveys for prey-is an unsophisticated approach to investigating the foraging ecology of Balaenoptera spp. Published results of the JARPN II feasibility study demonstrate problems with the execution of field work. Data analyses were simplistic. Nonlethal studies into the foraging ecology of Balaenoptera spp., using far fewer resources, have produced more definitive information. The recent changes in the IWC SC review process should result in unambiguous advice on how to improve the design of JARPN II. If the review recommends improvements that are not acted upon by the program's proponents, the IWC may need to decide whether the JARPN II program can be considered to be scientific research under Article VIII of the International Convention for the Regulation of Whaling.
\end{abstract}

KEY WORDS: Scientific whaling · Foraging ecology · Fisheries interactions - Scientific review Resale or republication not permitted without written consent of the publisher

\section{Introduction}

Whaling conducted by the Institute of Cetacean Research (ICR) is attracting considerable public attention. The latest example is a 7-part television series on Sea Shepherd's campaign to disrupt ICR's activities in the Antarctic (http://animal.discovery. com/tv/whale-wars/). The scientific community is also interested in the ICR's whaling program; e.g. Normile (2008, p. 26) questions whether the program is 'scientific investigation or disguised commercial whaling'. This is not the first time that the intent of ICR's whaling programs has been questioned in the scientific literature (e.g. Clapham et al. 2003, Gales et al. 2005).

The formal process for assessing the scientific value of research whaling entails review by an expert panel appointed by the Scientific Committee (SC) of the International Whaling Commission (IWC). The results from the 'Japanese Whale Research Program under
Special Permit in the western North Pacific - Phase II' (JARPN II) program are soon to be reviewed (Normile 2008). New guidelines state that scientists associated with the project being reviewed 'will participate in a primarily advisory role' (DeMaster et al. 2007, p. 351), rather than being full participants in the review process as they have been in the past.

\section{IWC SC reviews of lethal sampling programs}

Skepticism exists regarding the IWC SC review process for 'scientific whaling' programs because, as a previous Chair of the IWC SC stated, the reviews 'reflect differing views but come to no conclusions' (Normile 2000, p. 2265). The results of a December 2006 review of Japanese whaling under special permit in the Antarctic (JARPA) are instructive. JARPA's principal objective was to estimate biological para- 
meters, especially natural mortality, of Antarctic minke whales Balaenoptera bonaerensis. The program collected biological data on 6778 minke whales lethally sampled over 18 yr (Anonymous 2007).

Using cross-sectional sampling to estimate natural mortality of a population of free-ranging mammals is extremely difficult (Caughley 1977). Soon after JARPA started, its design was identified as unlikely to result in usable estimates of natural mortality (de la Mare 1990). The recent review concluded that 'the natural mortality rate had, for practical purposes, not been determined. In particular, even a zero value was not excluded by the analysis' (Anonymous 2007, p. 19). For comparison, a longitudinal study (mark-recapture) of survivorship in blue whales Balaenoptera musculus, based on the resightings of 238 ind. over $23 \mathrm{yr}$, resulted in annual survivorship estimates of $0.975 \pm 0.007$ (SE) (Ramp et al. 2006).

Despite failing to achieve its principal objective, the IWC SC 'concurred with the view of the 1997 workshop that "The results of the JARPA programme, while not required for management under the RMP [Revised Management Procedure], have the potential to improve management of minke whales in the Southern Hemisphere" in a number of ways' (www.iwcoffice. org/conservation/permits.htm). A new program, JARPA II, is now underway with a focus on ecosystem interactions; more whales of more species are being lethally sampled (Gales et al. 2005).

\section{JARPN II}

In the North Pacific, a 2 yr feasibility study (20002001) was conducted prior to the start of JARPN II. Results on feeding ecology and ecosystem components were published by Murase et al. (2007); '(T)he top priority in JARPN II deal with feeding ecology and ecosystem studies' (GJ 2002a, p. 4). Based on the feasibility study, 'the main purpose' of JARPN II 'is to study the competition between whales and fisheries, and to elucidate the role of the cetaceans in the marine ecosystem of the western North Pacific' (GJ 2002b, p. 4). Interactions between marine mammals and fisheries are a topic of current interest (e.g. Matthiopoulos et al. 2008), as is whether culling marine mammals can have a role in ecosystem-based fishery management (e.g. Harwood 2007).

\section{JARPN II feasibility study}

The JARPN II feasibility study examined prey found in the forestomachs of northern minke Balaenoptera acutorostrata and Bryde's B. edeni whales lethally sampled while simultaneous acoustic and trawl surveys of prey were carried out. It was a substantial undertaking, involving approximately 3 mo of sea time for each of 6 vessels (Murase et al. 2007).

\section{Sample collection}

According to the proponents of JARPN II, it is necessary to kill whales to collect more stomach samples, as '... commercial whaling had inherent bias. Random sampling of cetaceans should be required to remove the bias' (Murase et al. 2007, p. 186-187). Tracklines stratified into blocks were used to reduce the likelihood of biased sampling. Yet, because the original sampling design was altered at the block and transect scales, there is no guarantee that the newly collected data were unbiased. Results reveal 3 problems: a shift in original sampling sites, sampling of whales off-transect, and mismatch between the number of sighted and sampled whales.

The sampling sites for Bryde's whales in 2001 were altered from the original design to concentrate on areas where whales were at high densities (Murase et al. 2007 , p. 188). Several whales appear to have been lethally sampled off-transect (see Murase et al. their Fig. 2). Further, for minke whales in both years, and for Bryde's whales in 2001, there were more whales lethally sampled than there were primary (i.e. oneffort) sightings; only for Bryde's whales in 2000 were there more primary sightings than whales lethally sampled.

\section{Sampling of stomachs}

Analyses of prey selection were based on forestomach samples from 44 minke and 32 Bryde's whales, out of 233 whales sampled in total. Of these, 26 stomachs from minke whales and 16 from Bryde's whales (i.e. less than one-fifth of all animals sampled) contained undigested material. Including animals with digested material in the forestomach provides data of uncertain quality (e.g. Lindstrøm \& Haug 2001). Since lethally sampling whales to get their forestomach contents is such an inefficient technique, one may deduce that whales were sampled for reasons other than the primary aim of the program.

\section{Gender}

There was significant gender bias in the minke whales lethally sampled in both years. In $2000,87.5 \%$ of minke whales sampled were males, and in 2001, 93.0\% were 
males (GJ 2002a, Table 1.1.2 therein). For Bryde's whales in 2000, both sexes were sampled equally $(48.8 \%$ males), but in 2001 , only $34.0 \%$ of the whales sampled were male (GJ 2002a, Table 1.1.3 therein).

Gender-related differences in selective pressures influencing mammalian ecology have been discussed for some time (e.g. Darwin 1871). In baleen whales, differences in behavior of males and females have been reported for over 4 decades (e.g. Chittleborough 1965). Yet, in their Discussion, Murase et al. (2007) consistently make population-level inference from their data with no mention of gender bias in their samples.

Insights from the feasibility study

A suite of techniques have been developed to model the relationship between cetaceans and their habitat, including prey (see Redfern et al. 2006 for a review). Some techniques can handle spatially autocorrelated, heterogeneously sampled data such as that collected on the JARPN II feasibility study (e.g. Kaschner et al. 2006, Monestiez et al. 2006, Williams et al. 2006).

In 2001, 136 minke whales were sighted (primary and secondary sightings) and 100 of these were sampled, and 77 Bryde's whales were sighted and 50 sampled (sighting numbers from Fujise et al. 2002). Therefore, the samples appear to be a reasonable indicator of whale distribution. Murase et al. (2007, their Figs. 2c, 3c \& 4c) surveyed areas with high concentrations of anchovy and/or krill, but no whales.

This suggests that minke and Bryde's whales in the study area are not prey-limited. Sophisticated analysis using the appropriate modeling tools (Redfern et al. 2006) could therefore answer the first main question posed for JARPN II , namely 'to study the competition between whales and fisheries' (GJ 2002b, p. 4). Sensitivity analysis (e.g. Boyd 2002, Overholtz \& Link 2007) could be used to determine which model parameters need further research, and whether further lethal sampling is essential to address this question. Such modeling and sensitivity analyses should be available for the forthcoming review.

\section{Studying the ecosystem role of Balaenoptera spp.}

Given the emphasis in JARPN II on providing data for input into ecosystem modeling for fisheries management (Murase et al. 2007), it seems that the focus is on understanding the relationships between whales, their prey, and the oceanographic factors influencing the distributions of both.

Several studies have investigated these relationships. Stevick et al. (2008) showed that foraging by baleen whales and other predators did not affect euphausiid biomass on a small offshore bank, i.e. an absence of top-down control. Doniol-Valcroze et al. (2008) demonstrated that the distribution of blue, fin Balaenoptera physalus, and humpback Megaptera novaeangliae whales in a small area of the Gulf of St Lawrence was influenced by thermal fronts, but the distribution of minke whales appeared not to be. On a larger scale, Friedlaender et al. (2006) used Generalized Additive Models (GAMs) and classification trees to show strong, nonlinear relationships between the distribution and relative abundance of Antarctic minke and humpback whales in a large bay off the Western Antarctic Peninsula. Linking weather patterns, upwelling and euphausiid demography to blue whale distribution, abundance and foraging behaviour allowed Croll et al. (2005) to determine the sequence of physical and biological events that lead to the seasonal occurrence of blue whales in Monterey Bay. On a far larger spatiotemporal scale, comparable to the JARPN II study, Tynan (2004) used modern and historic whale surveys, oceanographic data and estimates of baleen whale food consumption, respiration and egestion to estimate decadal changes in their role in the carbon budget of the southeastern Bering Sea.

Research on Balaenoptera spp. has demonstrated nonlinear foraging thresholds (Piatt \& Methven 1992); differences in the foraging ecology between sympatric species (Tershy 1992); and differences in the foraging energetics of closely related species (e.g. AcevedoGutierrez et al. 2002, Goldbogen et al. 2007). A behavioural study based on photographic identification of individual northern minke whales demonstrated that they were specialist foragers (Hoelzel et al. 1989). This work has never been replicated, so it is unknown whether specialist foraging is commonplace in Balaenoptera spp.

None of this research required lethal sampling. As Balaenoptera spp. are gulp feeders (Goldbogen et al. 2007), stomach sampling reveals their recent meals, usually one species of schooling fish or crustacean. These patterns have been well known for decades (e.g. Nemoto 1959), so stomach sampling is no longer in common use internationally. The only other research programs that have used lethal sampling in recent decades have been those run by government marine science laboratories of the other whaling nations, Norway and Iceland.

\section{Upcoming review of JARPN II by the IWC}

Murase et al. (2007) used a resampling-based technique for hypothesis testing, using Manly's prey selectivity index. They found 4 cases of prey selection out of 
a possible 23 (site-species combinations), and 3 of 7 possible pairwise comparisons of these selectivity indices that differed. These were that male minke whales sampled over 6 d off Hokkaido in June 2001 selected walleye pollock Theragra chalcogramma over krill (thought to be Euphausia pacifica). Male minke whales sampled at 1 offshore site over 5 d in May 2001 selected Japanese anchovy Engraulis japonicus over krill. Bryde's whales at 1 site offshore sampled over $3 \mathrm{~d}$ in August 2000 also selected anchovy over krill. No consistent prey selection was observed across whale species, prey species, sites or years.

The JARPN II feasibility study has therefore generated little substantive information, given that it required approximately 18 ship-months of sea time. The other studies cited above used far fewer resources to arrive at more definitive answers.

The ICR hopes to use the findings of the JARPN II review to refine its research whaling program (Normile 2008). There is an implicit understanding that lethal sampling must remain part of JARPN II. The new guidelines for IWC SC reviews call for the review panel to make suggestions on how a program could be improved using other techniques (DeMaster et al. 2007). Past IWC SC reviews provided critical comment on the detail of research output, but failed to offer clear advice on how to resolve the problems identified, and contracting governments are under no obligation to act on advice given.

Given Japanese calls for decisions at the IWC to be based on science (Morishita 2006), if a transparent, unbiased scientific review recommends major changes to JARPN II, the ICR should accept the advice and make changes. If such a review finds that JARPN II is excellent science, its critics should also accept the review panel's advice.

But what if, once again, the IWC SC proves incapable of providing clear advice on handling its most contentious problem? As Clapham et al. (2003) pointed out, the question with regard to ICR's programs is: just how badly can something called science be done, before rejecting its claim to being science becomes something other than a matter of opinion? Rather than a scientific issue, this becomes a question for philosophers of science, and resolving the issue in the context of the IWC will require the involvement of professionals experienced at international treaty negotiation. If the JARPN II review fails to deliver clear advice, the IWC plenary will need to convene a meeting in a further attempt to resolve this long-running controversy. This meeting will need to adjudicate on when whaling can, and cannot, be considered to be scientific research under Article VIII of the International Convention for the Regulation of Whaling.
Acknowledgements. This work was partially funded by WWF International. Thanks to S. Holt, G. Notarbartolo di Sciara, M. Simmonds and S. Van Parijs for reviewing previous versions of this manuscript.

\section{LITERATURE CITED}

Acevedo-Gutiérrez A, Croll DA, Tershy BR (2002) High feeding costs limit dive time in the largest whales. J Exp Biol 205:1747-1753

Anonymous (2007) Report of the intersessional workshop to review data and results from Special Permit research on minke whales in the Antarctic. Paper SC/59/Rep1 presented to the IWC Scientific Committee meeting 2007 (available from the International Whaling Commission, The Red House, 135 Station Road, Cambridge CB24 9NP, UK)

Boyd IL (2002) Estimating food consumption of marine predators: Antarctic fur seals and macaroni penguins. J Appl Ecol 39:103-119

Caughley G (1977) Analysis of vertebrate populations. John Wiley \& Sons, New York

Chittleborough RG (1965) Dynamics of two populations of the humpback whale, Megaptera novaeangliae (Borowski). Aust J Mar Freshw Res 16:33-128

Clapham PJ, Berggren P, Friday NA, Kell L and others (2002) The JARPN II program: a critique. Paper SC/54/O26 presented to the IWC Scientific Committee 2002 (available from the International Whaling Commission, The Red House, 135 Station Road, Cambridge CB24 9NP, UK)

Clapham PJ, Berggren P, Childerhouse S, Friday NA and others (2003) Whaling as science. Bioscience 53:210-212

Croll DA, Marinovic B, Benson S, Chavez FB, Black N, Ternullo R, Tershy BR (2005) From wind to whales: trophic links in a coastal upwelling system. Mar Ecol Prog Ser 289:117-130

Darwin C (1871) The descent of man and selection in relation to sex. Murray, London

de la Mare W (1990) Problems of 'scientific' whaling. Nature 345:771

DeMaster D, Palka D, Bjorge A, Donovan G (2007) Revised suggestions for improved review of Special Permit proposals and results within the Scientific Committee. J Cetacean Res Manag 9(Suppl):350-352

Doniol-Valcroze T, Berteaux D, Larouche P, Sears R (2007) Influence of thermal fronts on habitat selection by four rorqual whale species in the Gulf of St. Lawrence. Mar Ecol Prog Ser 335:207-216

Estes JA, Riedman ML, Staedler MM, Tinker MT, Lyon BE (2003) Individual variation in prey selection by sea otters: patterns, causes and implications. J Anim Ecol 72:144-155

Friedlaender AS, Halpin PN, Qian S, Lawson GL, Wiebe PH, Thiele D, Read AJ (2006) Whale distribution in relation to prey and oceanographic processes in the western Antarctic Peninsula shelf waters. Mar Ecol Prog Ser 317:297-310

Fujise Y, Tamura T, Bando T, Watanabe $\mathrm{H}$ and others (2002) Cruise report of the feasibility study of the Japanese whales research program under special permit in the western North Pacific - Phase II (JARPN II) in 2001. Paper SC/54/O16 presented to the IWC Scientific Committee 2002 (available from the International Whaling Commission, The Red House, 135 Station Road, Cambridge CB24 9NP, UK)

Gales NJ, Kasuya T, Clapham PJ, Brownell RL (2005) Japan's whaling plan under scrutiny. Nature 435:883-884

Goldbogen JA, Pyenson ND, Shadwick RE (2007) Big gulps 
require high drag for fin whale lunge feeding. Mar Ecol Prog Ser 349:289-301

GJ (Government of Japan) (2002a) Report of 2000 and 2001 feasibility study of the Japanese Whale Research Program under Special Permit in the western North Pacific Phase II (JARPN II). In: Fujise Y, Kawahara S, Pastene LA, Hatanaka H (eds) Paper SC/54/O17 presented to the IWC Scientific Committee meeting 2002 (available from the International Whaling Commission, The Red House, 135 Station Road, Cambridge CB24 9NP, UK)

GJ (Government of Japan) (2002b) Research plan for cetacean studies in the Western North Pacific under special permit (JARPN II). Paper SC/54/O2 presented to the IWC Scientific Committee meeting 2002 (available from the International Whaling Commission, The Red House, 135 Station Road, Cambridge CB24 9NP, UK)

Harwood J (2007) Is there a role for ecologists in an ecosystem approach to the management of marine resources? Aquat Conserv Mar Freshw Ecosyst 17:1-4

Hoelzel AR, Dorsey EM, Stern SJ (1989) The foraging specializations of individual minke whales. Anim Behav 38: 786-794

Kaschner K, Watson R, Trites AW, Pauly D (2006) Mapping world-wide distributions of marine mammal species using a relative environmental suitability (RES) model. Mar Ecol Prog Ser 316:285-310

Lindstrøm U, Haug T (2001) Feeding strategy and prey selectivity in common minke whales (Balaenoptera acutorostrata) foraging in the southern Barents Sea during early summer. J Cetacean Res Manag 3:239-249

Matthiopoulos J, Smout S, Winship AJ, Thompson D, Boyd IL, Harwood J (2008) Getting beneath the surface of marine mammal-fisheries competition. Mammal Rev 38: $167-188$

Monestiez P, Dubroca L, Bonnin E, Durbec JP, Guinet C (2006) Geostatistical modelling of spatial distribution of Balaenoptera physalus in the northwestern Mediterranean Sea from sparse count data and heterogeneous observation efforts. Ecol Model 193:615-628

Morishita J (2006) Multiple analysis of the whaling issue:

Editorial responsibility: Otto Kinne,

Oldendorf/Luhe, Germany understanding the dispute by a matrix. Mar Policy 30: 802-808

Murase H, Tamura T, Kiwada H, Fujise Y and others (2007) Prey selection of common minke (Balaenoptera acutorostrata) and Bryde's (Balaenoptera edeni) whales in the western North Pacific in 2000 and 2001. Fish Oceanogr 16:186-201

Nemoto T (1959) Food of baleen whales with reference to whale movements. Sci Rep Whales Res Inst 14:149-290

Normile D (2000) Japan's whaling program carries heavy baggage. Science 289:2264-2265

Normile D (2008) Panel to take closer look at scientific whaling. Science 321:26

Overholtz WJ, Link JS (2007) Consumption impacts by marine mammals, fish, and seabirds on the Gulf of Maine-Georges Bank Atlantic herring (Clupea harengus) complex during the years 1977-2002. ICES J Mar Sci 64:83-96

Piatt JF, Methven DA (1992) Threshold foraging behavior of baleen whales. Mar Ecol Prog Ser 84:205-210

Ramp C, Bérubé M, Hagen W, Sears R (2006) Survival of adult blue whales Balaenoptera musculus in the Gulf of St. Lawrence, Canada. Mar Ecol Prog Ser 319:287-295

Redfern JV, Ferguson MC, Becker EA, Hyrenbach KD and others (2006) Techniques for cetacean-habitat modelling. Mar Ecol Prog Ser 310:271-295

Stevick PT, Incze LS, Kraus SD, Rosen S, Wolff N, Baukus A (2008) Trophic relationships and oceanography on and around a small offshore bank. Mar Ecol Prog Ser 363:15-28

- Tershy BR (1992) Body size, diet, habitat use, and social behavior of Balaenoptera whales in the Gulf of California. J Mammal 73:477-486

Tynan CT (2004) Cetacean populations on the SE Bering Sea shelf during the late 1990s: implications for decadal changes in ecosystem structure and carbon flow. Mar Ecol Prog Ser 272:281-300

Williams R, Hedley SL, Hammond PS (2006) Modeling distribution and abundance of Antarctic baleen whales using ships of opportunity. Ecol Soc 11(1):1 (available at: www. ecologyandsociety.org/vol11/iss1/art1/)

Submitted: July 29, 2008; Accepted: December 8, 2008 Proofs received from author(s): January 16, 2009 